\title{
PENGEMBANGAN AUGMENTED REALITY BOOK SEBAGAI MEDIA PEMBELAJARAN VIRUS BERBASIS ANDROID
}

\author{
Kadek Agus Kamiana ${ }^{1}$, Made Windu Antara Kesiman², Gede Aditra Pradnyana ${ }^{3}$ \\ Jurusan Pendidikan Teknik Informatika \\ Universitas Pendidikan Ganesha \\ Singaraja,Bali \\ e-mail:agusid99@gmail.com ${ }^{1}$, antara.kesiman@undiksha.ac.id², gede.aditra@undiksha.ac.id ${ }^{3}$
}

\begin{abstract}
ABSTRAK
Penelitian ini bertujuan untuk merancang dan mengetahui respon siswa kelas X MIA (Matematika Ilmu Alam) dari hasil rancangan Aplikasi Augmented Reality Book Virus. Metode penelitian yang digunakan adalah pengembangan untuk mengembangkan Aplikasi Augmented Reality Book Virus sebagai media pembelajaran. Aplikasi ini menggunakan library Vuforia yang mampu memainkan suara dan menampilkan objek 3D animasi dan objek 3D virus, diputar oleh user ke dalam sebuah lingkungan nyata dengan menggunakan bantuan buku dan smartphone berbasis Android. Hasil penelitian dan pengembangan menggunakan metode ADDIE menunjukkan bahwa aplikasi augmented reality book virus dalam kriteria sangat baik. Hasil yang diperoleh berdasarkan analisis uji black box diperoleh presentase keberhasilan $100 \%$, uji white box diperoleh presentase keberhasilan $100 \%$, uji ahli isi persentase keseluruhan penilaian yaitu $98.67 \%$, uji ahli media dapat dianalisa persentase keseluruhan penilaian yaitu $89,23 \%$, dan uji lapangan diketahui bahwa rerata presentase dari 15 subyek (butir) penilaian yaitu 82,92\% sehingga aplikasi augmented reality book virus masuk dalam kriteria sangat baik. Kesimpulan yang didapat yaitu sudah berhasil mengembangkan aplikasi augmented reality book sebagai media pembelajaran virus berbasis android dan sudah berhasil mendeskripsikan respon siswa terhadap pengembangan aplikasi augmented reality book virus pada pelajaran virus.
\end{abstract}

Kata kunci: Augmented Reality Book, Vuforia, Android, Virus, Objek 3D

\section{ABSTRACT}

This study was designed to discuss and understand the responses of students of class X MIA (Mathematics of Natural Sciences) from the results of the application of the Augmented Reality Virus Application. The research method used is the development to develop the Augmented Reality Virus Application as a learning media. This application uses the Vuforia library which is able to play sounds and display 3D animated objects and 3D virus objects, played by users into a real environment using the help of Android-based books and smartphones. The results of research and development using the ADDIE method show that the application of augmented reality book virus is in very good criteria. The results obtained based on the black box test analysis obtained a success percentage of $100 \%$, the white box test obtained a percentage of success $100 \%$, expert test the contents of the overall percentage of the assessment is $98.67 \%$, the media expert test can be analyzed the overall percentage of assessment is $\mathbf{8 9 . 2 3 \%}$, and the field test shows that the average percentage of 15 subjects (items) is $82.92 \%$ so that augmented reality applications book viruses are included in very good criteria. The conclusion is that it has succeeded in developing the augmented reality book application as an Android-based virus learning media and has succeeded in describing students' responses to the development of augmented reality book virus applications in virus learning.

Keywords : Augmented Reality Book, Vuforia, Android, Virus, Objek 3D

\section{PENDAHULUAN}

Di era globalisasi ini perkembangan teknologi informasi semakin berkembang. Dalam dunia Pendidikan Perkembangan IPTEK terhadap proses pembelajaran adalah diperkayanya sumber belajar dan media pembelajaran (Suputra, 2016). Melihat era modern yang semakin maju dan semakin berkembang saat ini, tanpa disadari banyak sekali ancamanancaman yang ada terutama pada tubuh manusia. Virus merupakan salah satu ancaman yang ada pada tubuh manusia. Penelitian dan penemuan tentang virus sudah lama ditemukan oleh para ilmuan. Dikarenakan banyaknya macam bentuk virus maka banyak yang ingin mempelajarinya atau biasa disebut virologi. Mata pembelajan virus sudah didapatkan khususnya pada bangku sekolah dasar. Tetapi hanya sebagian kecil dari informasi dari virus. Kemudian pada tahap SMA, pada kelas 10 materi virus dibahas lebih mendalam lagi dengan adanya beberapa praktek pengenalan virus dengan menggunakan mikroskop. Namun dalam peneliti menemukan beberapa permasalahan yang mengakibatkan pembelajaran virus tersebut menjadi kurang efektif.

Dalam pelaksanaan praktek dalam pembelajaran virus, tentunya diperlukan banyak alat seperti mikroskop mengingat jumlah siswa dalam satu kelas rata-rata sekitar 30-35 siswa, tentunya ini menyebabkan terbatasnya alat yang digunakan dalam praktek, sehingga alat tersebut digunakan secara bergiliran atau kelompok. Sementara materi tentang virus sulit untuk dilihat secara langsung karena ukurannya dari virus tersebut yang sangat kecil. Selain itu terdapat masalah lain yaitu terbatasnya media pembelajaran seperti buku ajar (Buku Paket). Permasalahan tersebut juga merupakan permasalahan umum yang dialami berbagai sekolah. 
Berdasarkan menyebarkan angket kepada guru dan 30 orang siswa di Jurusan MIA (Matematika Ilmu Alam). Dalam pelaksanaan praktek, buku ajar sangat berperan. Buku merupakan sumber informasi atau materi yang terkait dalam pelaksanaan praktek. Namun $83,3 \%$ siswa menyatakan bahwa Buku/LKS yang digunakan dalam pembelajaran kurang memberikan kejelasan materi, dikarenakan susah dipahami jika pembelajaran berbasis teks, sehingga pemahaman siswa dalam memahamı materi pembelajaran kurang maksimal. Sebanyak $80 \%$ siswa menyatakan bahwa media gambar yang terdapat di Buku/LKS tidak membantu memperjelas bentuk dari virus tersebut dan hanya terdapat tulisan dan contoh yang diberikan sedikit. Sebanyak 93,3\% siswa menyatakan kurang berminat terhadap konten yang terdapat pada buku.

Beberapa penelitian sebelumnya yang pernah menyinggung hal ini adalah implementasi augmented reality mengenai organ mata. Melalui hasil penelitiannya (Nurlifa, 2016) menyatakan bahwa hasil dari penelitiannya augmented reality organ mata memiliki tingkat kepuasan yang tinggi mengenai hasil dari tampilan, pemahaman dalam belajar dan ketertarikan pengguna dalam mempelajari organ mata dengan menggunakan augmented reality. Penelitian lain yang dilakukan (Mauludin, 2017) membahas tentang penerapan augmented reality sistem pencernaan. Secara umum hasil dari uji ahli isi dan ahli media menyatakan bahwa modul dan aplikasi layak uji coba lapangan, serta respon siswa terhadap aplikasi sistem pencernaan berbasis Augmented Reality sangat positif.

Berdasarkan uraian diatas, maka dengan bantuan Augmented Reality, maka pada peneliti mencoba untuk mengintegrasikan AR ke dalam pembelajaran, dengan bantuan Augmented Reality ini, diharapkan proses pembelajaran yang dilalui oleh siswa menjadi lebih interaktif dan menyenangkan, maka penelitian ini akan dikembangkan sebuah media berupa aplikasi Augmented Reality Book yang menampilkan objek nyata virus berupa animasi 3 dimensi serta penjelasannya yang berjudul "Pengembangan Aplikasi Augmented Reality Book Sebagai Media Pembelajaran Virus Berbasis Android".

\section{KAJIAN TEORI}

\section{A. Materi Virus}

1. Sejarah Virus

Penyelidikan tentang objek-objek berukuran kecil dimulai sejak ditemukannya mikroskop oleh ilmuan Belanda bernama Antony van Leeuwenhoek (1632-1723). Berkat penemuan mikroskop tersebut, berbagai penelitian tentang objek-objek mikroskopis mulai berkembang. Berbagai penelitian itu kemudian berkembang semakin pesat sejalan dengan perkembangan mikroskop.

Perkembangan mikroskop ini mendorong berbagai penemuan di bidang biologi, seperti penemuan sel, bakteri, dan partikel mikroskopis dan virus. Penemuan virus melalui perjalanan panjang dan melibatkan penelitian dari banyak ilmuwan. Sejarah penemuan virus dimulai pada tahun 1882 dengan adanya penyakit yang menimbulkan bintik kekuningan pada daun tembakau.

\section{Ciri-ciri virus}

Berikut ini adalah struktur virus secara umum.

a. Virus bersifat aseluler (tidak mempunyai sel)

b. Virus berukuran jauh lebih kecil daripada bakteri, yakni berkisar antara 20 milimikron-300 milimikron (1 mikron 1.000 milimikron). Untuk mengamatinya diperlukan mikroskop elektron yang pembesarannya dapat mencapai 50.000x

c. Virus hanya memiliki salah satu macam asam nukleat (RNA atau DNA).

d. Virus umumnya berupa hablur (kristal).

e. Bentuk virus bervariasi. Ada virus berbentuk oval, silinde polihedral, dan kompleks. Bentuk virus yang kompleks terdiri atas kepala yang berbentuk polihedral, ekor yang berbentuik silinder, dan serabut ekor. Virus berbentuk kompleks misalnya bakteriofag, yaitu jenis virus yang menginfeksi bakteri

f. Tubuh virus terutama tersusun atas asam nukleat yang diselubungi oleh protein yang disebut kapsid. Virus yang struktur tubuhnya terdiri atas asam nukleat dan seluruh protein disebut virion.

3. Perkembangan Virus

Ada dua macam cara virus menginfeksi bakteri, yaitu secara litik dan secara lisogenik. Pada infeksi secara litik, virus akan menghancurkan sel induk setelah berhasil melakukan reproduksi. Pada secara lisogenik, virus tidak menghancurkan sel, tetapi berintegrasi dengan DNA sel induk. Dengan demikian, virus akan bertambah banyak pada saat sel inang membelah.

4. Peran Vvirus dalam kehidupan manusia

Pada umumnya virus bersifat merugikan. Virus dapat menginfeksi tumbuhan tumbuhan, hewan, dan manusia sehingga menimbulkan penyakit. Salah satu contoh penyakit yang disebabkan virus adalah Influenza, AIDS dan Polio.

\section{B. Media Pembelajaran}

Media pembelajaran berasal dari bahasa latin dan merupakan bentuk jamak dari "medium" yang yang berarti "perantara" atau "pengantar" sumber pesan dengan penerima pesan. Media pembelajaran sangat penting dalam memberikan infomasi ataupun pengajaran. Menurut (Riyana, 2007) dalam buku "Media Pembelajaran", pembelajaran merupakan suatu kegiatan yang melibatkan seseorang dalam upaya memperoleh pengetahuan, keterampilan dan nilai-nilai positif dengan memanfaatkan berbagai sumber untuk belajar.

Menurut (Lisiswanti, 2015) menjelaskan, media pembelajaran adalah media-media yang digunakan dalam pembelajaran, yaitu meliputi alat bantu guru dalam mengajar serta sarana pembawa pesan dari sumber belajar ke penerima pesan belajar (siswa). Manfaat dari penggunaan media pembelajaran adalah dapat memperjelas penyajian pesan dan informasi. Dengan menggunakan media pembelajaran, pengajar dapat meningkatkan minat dan mempermudah untuk mengarahkan perhatian siswa saat kegiatan

pembelajaran berlangsung. Hal itu menyebabkan siswa termotivasi untuk giat belajar dan aktif dalam kegiatan pembelajaran (Mauludin et al, 2017). 


\section{Animasi 3 Dimensi}

Menurut (Suheri 2006), mendefinisikan bahwa animasi adalah kumpulan gambar yang diolah sedemikian rupa sehingga menghasilkan gerakan. Menurut (Harsadi, 2016), Perkembangan teknologi dan komputer membuat teknik pembuatan animasi 3D semakin berkembang dan maju pesat. Animasi 3D adalah pengembangan dari animasi 2D yang dapat dilihat dari berbagai bidang. Dengan animasi 3D karakter yang diperlihatkan semakin hidup dan mendekati nyata dari bentuk aslinya. Animasi 3D membutuhkan proses yang relatif lebih sederhana dibandingkan dengan animasi 2D karena semua proses bisa langsung dikerjakan dalam satu komputer software.

D. Tools Pengembangan

a. Vuforia

Vuforia adalah Augmented Reality Software Development Kit (SDK) untuk perangkat mobile yang memungkinkan pembuatan aplikasi AR. AR Vuforia memberikan cara berinteraksi yang memanfaatkan kamera pada mobile phones untuk digunakan sebagai perangkat masukan, sebagai mata elektronik yang mengenali penanda tertentu, sehingga di layar bisa ditampilkan perpaduan antara dunia nyata dan dunia yang digambar oleh aplikasi.

\section{b. Unity $3 D$}

Aplikasi unity $3 D$ adalah game engine merupakan sebuah software pengolah gambar, grafik, suara, input, dan lain-lain yang ditujukan untuk membuat suatu game, meskipun tidak selamanya harus untuk game. Unity mampu di publish menjadi Standalone (.exe), berbasis web, Android, IoS Iphone, XBOX, dan PS3. Walau bisa dipublish ke berbagai platform, Unity perlu lisensi untuk dapat dipublish ke platform tertentu. Tetapi Unity menyediakan untuk free user dan bisa di publish dalam bentuk Standalone (.exe) dan web. Untuk saat ini Unity sedang di kembangkan berbasis AR (Augmented Reality).

c. Android

Android adalah sebuah sistem operasi untuk perangkat mobile berbasis linux yang mencangkup sistem operasi, middleware dan aplikasi Android menyediakan platform terbuka bagi para pengembang untuk menciptakan aplikasi mereka.

\section{d. Blender}

Blender adalah perangkat lunak sumber terbuka grafika komputer 3D. Perangkat lunak ini digunakan untuk membuat film animasi, efek visual, model cetak 3D, aplikasi 3D interaktif dan permainan video. Blender memiliki beberapa fitur termasuk pemodelan 3D, penteksturan, penyunting gambar bitmap, penulangan, simulasi cairan dan asap, simulasi partikel, animasi, penyunting video, pemahat digital, dan rendering.

e. Augmented Reality Book

Menurut (Andriyadi, 2011) menyatakan augmented reality (AR) adalah penggabungan antara objek virtual dengan objek nyata. Menurut definisi Ronald T. Azuma dalam kutipan (Utami, 2015) yaitu yang pertama adalah augmented reality merupakan penggabungan dunia nyata dan virtual, kedua augmented reality berjalan secara interaktif dalam waktu nyata (realtime) dan yang ketiga bahwa terdapat integrasi antar benda dalam tiga dimensi, yaitu benda maya terintegrasi dalam dunia nyata. Sehingga suatu benda yang sebelumnya hanya dapat dilihat secara dua dimensi, dapat muncul sebagai objek virtual yang digabungkan dalam lingkungan nyata secara real time. Berdasarkan pendapat para ahli di atas maka dapat disimpulkan bahwa Augmented Reality adalah sebuah pengintegrasian benda/objek maya yang didesain seolah-olah berada di dunia nyata sehingga pengguna dapat melakukan interaksi dengan objek tersebut.

f. Augmented Reality Book

Augmented Reality Book (AR-Book) atau yang dalam bahasa Indonesia berarti buku berbasis augmented reality merupakan penggabungan antara buku biasa dengan teknologi AR. AR-Book secara garis besar memiliki dua komponen utama, yaitu buku yang dilengkapi dengan marker berjenis Quick Response Code (ORC) pada hampir setiap halamannya, dan yang kedua yaitu peralatan untuk menangkap marker dan menampilkan hasilnya. Augmented Reality Book termasuk dalam kategori sumber belajar yang didesain khusus, karena dikembangankan sebagai komponen dalam hal mempermudah penggunaan memahami isi buku dengan cara menampilkan objek berupa 3 dimensi pada gambar 2 dimensi yang tertera pada buku.

\section{METODE}

Penelitian ini merupakan Penelitian dan Pengembangan dalam bahasa inggrisnya Research and Development. R\&D dideskripsikan merupakan metode penelitian yang digunakan untuk menghasilkan suatu produk tertentu serta menguji keefektifan dari produk yang dibuat.

Desain pengembangan dalam penelitian ini menggunakan model Analysis Design Development Implementation Evaluation (ADDIE). Sesuai dengan namanya, model ADDIE terdiri dari lima tahapan yaitu tahapan Analyze, Design. Development, Implementation, and Evaluation. Adapun desain pengembangan berdasarkan model ADDIE dapat dilihat pada gambar 1 .

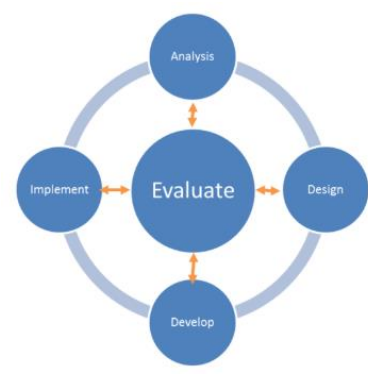

\section{Gambar .1. Model pemgembangan ADDIE (Sumber : rapidbi.com)}

Analysis Pada tahap ini peneliti melakukan 4 analisa analisis kegiatan, antara lain analisis kurikulum, analisis karakteristik peserta didik, analisis sumber belajar, serta analisis kebutuhan. Design, pada tahap ini peneliti melakukan rancangan aplikasi, model fungsional perangkat lunak, perancangan arsitektur perangkat lunak dan rancangan antarmuka aplikasi. 
Development, pada tahap ini peneliti melakukan kegiatan produksi Augmented Reality Book seperti tahap modeling objek 3D, proses animasi, pencocokan objek 3D dengan marker serta mempersiapkan media buku yang menampilkan informasi yang diperlukan. Implementation, pada tahap ini peneliti melakukan menggandakan/memproduksi media yang telah dikembangkan dalam bentuk aplikasi dan buku Augmented Reality, kemudian melakukan pelatihan kepada guru dan melakukan uji lapangan. Evaluation, pada tahap ini peneliti melakukan evaluasi untuk melakukan perbaikan terhadap media pembelajaran yang telah dikembangkan.

\section{HASIL DAN PEMBAHASAN}

\section{Hasil Penelitian}

Hasil penelitian "Pengembangan Aplikasi Augmented Reality Book Sebagai Media Pembelajaran Virus Berbasis Android" dengan menggunakan model ADDIE. Berikut ini akan dijabarkan mengenai beberapa tahapan terkait dengan hasil evaluasi dari Pengembangan Aplikasi Augmented Reality Book Sebagai Media Pembelajaran Virus Berbasis Android" diantaranya yaitu tahap Analysis (analisa), tahap Design (desain), tahap Development (pengembangan), tahap Implementation (implementasi), dan tahap Evaluation (evaluasi).

A. Analysis

Disini peneliti melakukan analisi kebutuhan yang akan dibagi menjadi 4 bagian analisis yakni analisis kurikulum, analisis karakteristik peserta didik, analisis sumber belajar, serta analisis kebutuhan.

\section{- Analisis Kurikulum}

Pada analisi ini penulis melakukan kegiatan analisis pembelajaran sesuai dengan indikator pencapaian serta kompetensi yang terkandung dalam kurikulum di tempat penelitian dengan metode wawancara kepada guru.

- Analisis Karakteristik Peserta didik

Analisis karakteristik peserta didik dilakukan dengan cara wawancara dengan guru dan siswa untuk mengetahui karakteristik peserta didik yang akan digunakan pegangan dan acuan dalam pengembangan Aplikasi Kebutuhan Non Fungsional

- Analisis Sumber Belajar

Sumber belajar yang digunakan pada pembelajaran virus salah satunya adalah buku LKS dan buku paket.

- Analisis Kebutuhan

1. Kebutuhan Fungsional

[1] Pengguna dapat menampilkan informasi tentang cara penggunaan dari aplikasi Augmented Reality Virus, Pengguna dapat mengunduh buku AR yang didalamnya terdapat marker, [2] Pengguna mampu menampilkan objek 3D virus dengan menggunakan buku sebagai media pendukung penggunaan aplikasi ini, [3] Objek 3D ini akan ditampilkan berdasarkan marker didalam buku yang berfungsi menampilkan objek 3D virus yang dilengkapi penjelasan tentang virus secara umum, [4] perkembangbiakan virus dan jenis-jenis virus dalam kehidupan, Pengguna mampu menampilkan informasi tentang aplikasi dan identitas pengembang dengan menekan tombol tentang.

2. Kebutuhan Non Fungsional

[1] Berjalan pada perangkat dengan sistem operasi Android minimal versi 4.1 (Jelly Bean). [2] Memiliki tampilan user friendly, tujuannya agar pengguna tidak kesulitan dalam menggunakan aplikasi dan tertarik untuk menggunakan aplikasi. User friendly yang dimaksud yaitu perpaduan warna yang menarik antara background dan softbutton, serta kemudahan dalam penggunaan aplikasi dengan tampilan antar muka yang simple dan mudah dipahami baik oleh anak-anak maupun orang dewasa.

\section{B. Design}

Pada tahap desain lebih menfokuskan untuk menciptakan sistem yang mudah digunakan dan dimengerti user, dapat dilihat pada gambar 2 :

\section{- Rancangan aplikasi}

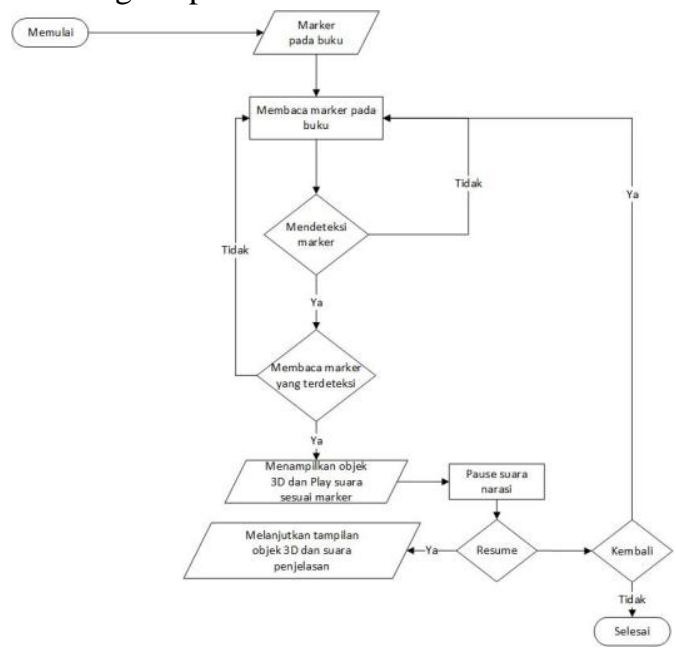

Gambar 2. Flowchart Rancangan Aplikasi

\section{- Model Fungsional Perangkat Lunak}

Pada model fungsional perangkat lunak menjelaskan gambaran umum dari perangkat lunak Mulai dari pembuatan objek 3 dimensi, pembuatan file suara, pencarian dan pembentukan gambar sehingga menjadi library marker, digabungkan menjadi satu projek augmented reality ditambah library AR (augmented reality) dan proses coding yang merupakan komponen utama pengembangan perangkat lunak augmented reality. 
P-ISSN 2252-9063

Kumpulan Artikel Mahasiswa Pendidikan Teknik Informatika

(KARMAPATI)

Volume 8 Nomor 2 Tahun 2019

\section{KคRmดPดTI}

- Perancangan arsitektur perangkat lunak dapat dilihat pada gambar 3.

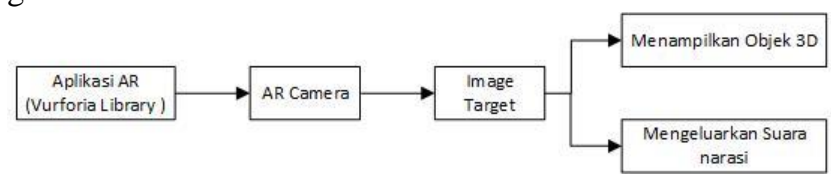

Gambar 3. Structur Chart Augmented Reality Book Virus

- Rancangan Antarmuka Aplikasi

Perancangan antarmuka perangkat lunak dimaksudkan untuk berinteraksi antara pengguna dengan perangkat lunak. Dapat dilihat pada gambar 4 dan gambar 5.

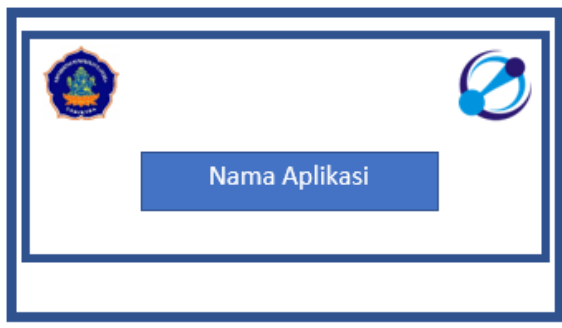

Gambar 4. Rancangan layar tampilan awal (Pembuka)

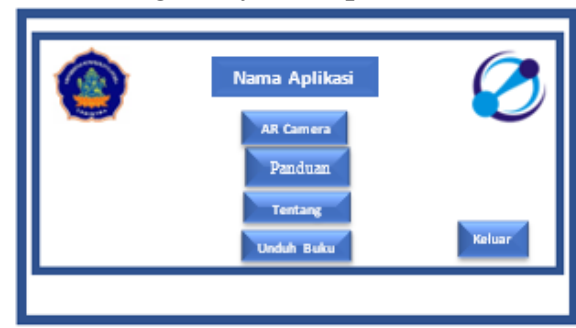

Gambar 5. Rancangan menu Utama

\section{Development}

Pada tahapan ini dilakukan pengembangan dari tahap desain adapun pengembangan yang di lakukan adalah pengembangan desain dan di implementasikan kedalam bentuk animasi, hasil pengembangan bisa di lihat pada penjelasan di bawah.

- Hasil Implemnetasi Perangkat Lunak dapat dilihat pada gambar 6, 7, 8, 9 .

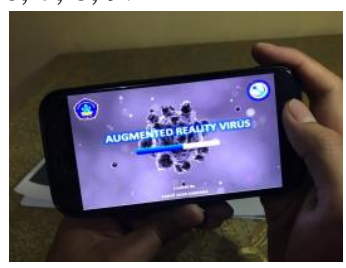

Gambar 6. Tampilan Screen Splash

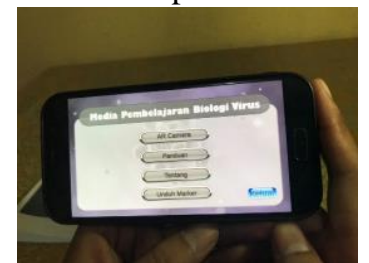

Gambar 7. Tampilan Menu

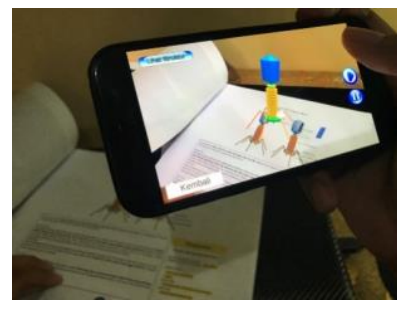

Gambar 8. Implementasi struktur virus

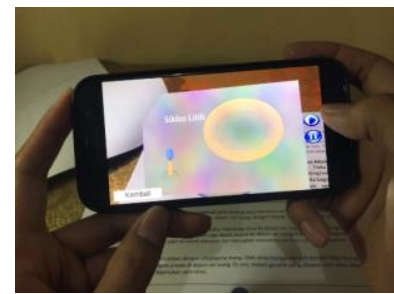

Gambar 9. Implementasi video reproduksi virus

- Hasil Objek 3 Dimensi dapat dilihat pada gambar 10 dan gambar 11.

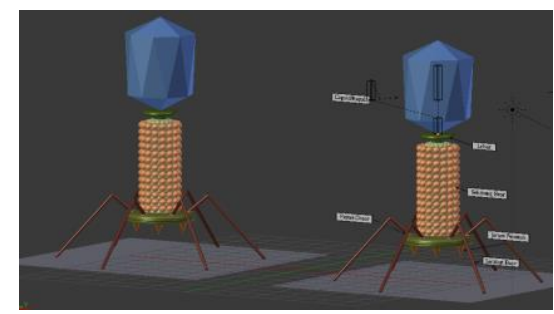

Gambar. 10 objek 3D struktur virus

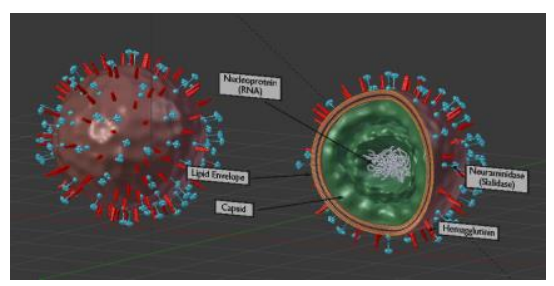

Gambar 11. Objek 3D virus influenza

\section{Implementation}

Pada tahap implementasi penulis juga menghasilkan produk akhir berupa cetakan buku AR yang menjadi paket satu dengan aplikasi berupa file apk yang bisa pasang pada smartphone, kemudian melakukan pelatihan penggunaan aplikasi kepada pengguna dan yang terakhir yaitu melakukan uji lapangan di SMA Negeri 2 banjar.

\section{E. Evaluation}

Setelah tahap implementasi selesai, kemudian dilanjutkan ke tahap berikunya yaitu tahap evaluasi. Evaluasi yang dilakukan adalah evalusi secara fomatif dan sumatif. Evaluasi formatif bertujuan untuk merevisi aplikasi sesuai dengan penilaian dan saran perbaikan yang diberikan oleh ahli isi dan ahli media. Sedangkan evaluasi sumatif bertujuan untuk menganalisa dan kemudian mendeskripsikan respon siswa kelas 
X MIA SMA Negeri 2 Banjar terhadap aplikasi augmented reality book virus.

\section{Hasil Uji Blackbox}

Pada pengujian kasus uji 1 memiliki tujuan untuk menguji kebenaran proses Augmented Reality Book virus. Dari hasil pengujian diperoleh presentase keberhasilan $100 \%$ dan pada kasus uji 2 dilakukan untuk mengetahui apakah aplikasi yang dibuah sudah berjalan dengan baik dan benar dan dapat digunakan oleh orang lain. Dengan hasil pengujian menggunakan beberapa hardware diperolah hasi pengujian dengan presentase keberhasilan $100 \%$

\section{Hasil Uji Whitebox}

Pada pengujian whitekbox digunakan untuk mengetahui cara kerja suatu perangkat lunak secara internal. Dari hasil penguijan white box diperolah persentase keberhasil $100 \%$.

\section{Hasil Uji Ahli Isi}

Pada uji ahli isi, pengujian dilakukan oleh dua orang guru biologi di SMA Negeri 2 Banjar. Dengan didapat hasil persentase keseluruhan penilaian yaitu $98.67 \%$.

\section{Hasil Uji Ahli Media}

Pada uji ahli media, pengujian dilakukan oleh 2 ahli dari staf dosen di Jurusan Pendidikan Teknik Informatika UNDIKSHA singaraja. Dengan didapat presentase keseluruhan penilaian yaitu $89,23 \%$.

\section{Hasil Uji Lapangan}

Syarat untuk melakukan uji lapangan tentunya aplikasi pembelajaran sudah dinyatakan layak untuk uji coba lapangan tanpa revisi oleh ahli isi dan ahli media. Uji lapangan melibatkan 32 siswa dan didampingi langsung oleh guru. Dari hasil analisis Uji lapangan diketahui bahwa rerata presentase dari 15 subyek (butir) penilaian yaitu $83,50 \%$.

\section{Pembahasan}

Berdasarkan hasil pengembangan dapat diketahui bahwa aplikasi augmented reality book media pembelajaran virus berbasis android. yang dikembangkan sesuai dengan model ADDIE (Analyze, Design, Development, Implementation, Evaluation).

Berdasarkan hasil pengujian blackbox yakni Uji kasus 1 bertujuan untuk mengetahui kebenaran proses aplikasi Augmented Reality Book Sebagai Media Pembelajaran Virus Berbasis Android". Dengan hasil yakni semua proses mulai dari saat pertama kali aplikasi dijalankan sampai dengan selesai keluar dari aplikasi berfungsi dengan baik. Dari hasil pengujian kesesuaian proses tersebut, diperoleh presentase keberhasilan $100 \%$ dan 3 orang responden menyatakan semua animasi objek 3D yang ditampilkan sesuai, begitu pula dengan suara narasi yang ditampilkan oleh aplikasi. Sedangkan untuk Uji kasus 2 yakni aplikasi "Pengembangan Aplikasi Augmented Reality Book Sebagai Media Pembelajaran Virus Berbasis Android" pada perangkat hardware yang berbeda. Dengan tujuan untuk mengetahui apakah aplikasi yang dibuat sudah berjalan dengan baik dan benar dan dapat digunakan oleh orang lain oraing lain. Dari hasil pengujian pada beberapa hardware secara umum sudah dikatakan memuaskan. Dari hasil pengujian menggunakan beberapa hardware diperolah presentase keberhasilan $100 \%$ dan 3 orang reponden dapat menggunakan aplikasi.

Berdasarkan hasil pengujian whitebox yakni untuk mengetahui cara kerja suatu perangkat lunak secara internal untuk menjamin operasi-operasi internal sesuai dengan spesifikasi yang telah ditetapkan. Dari pengujian tersebut dapat disimpulkan bahwa semua fungsi code yang terdapat di Augmented Reality Book Virus berjalan dengan baik dan benar. Dari hasil penguijan white box diperolah persentase keberhasil $100 \%$

Berdasarkan hasil pengujian ahli isi yang dilakukan berfokus pada isi dari materi melalui yang ingin disampaikan melalui aplikasi. untuk menjamin bahwa isi materi sesuai dengan materi yang telah ditetapkan Pada uji ahli isi, pengujian dilakukan oleh dua orang guru biologi di SMA Negeri 2 Banjar. Berdasarkan penilaian dari ahli isi dapat dianalisa persentase keseluruhan penilaian yaitu $98.67 \%$, aplikasi Augmented Reality Book Virus berada dalam kriteria sangat baik.

Berdasarkan pengujian ahli media berfokus pada penilaian aplikasi untuk mendapatkan kesimpulan apakah aplikasi siap untuk uji coba lapangan atau tidak. Pada uji ahli media, pengujian dilakukan oleh 2 ahli, kedua ahli merupakan staf dosen di Jurusan Pendidikan Teknik Informatika UNDIKSHA singaraja. Berdasarkan penilaian dari ahli dapat dianalisa presentase penilaian yaitu 89,23\%, aplikasi Augmented Reality Book Virus berada dalam kriteria sangat baik.

Berdasarkan hasil respon pengguna yang dilakukan digunakan untuk mengetahui respon dari pengguna setelah menggunakan aplikasi augmented reality book virus yang peneliti kembangkan dengan melakukan uji respon pengguna. Untuk melakukan uji lapangan tentunya aplikasi pembelajaran sudah dinyatakan layak untuk uji coba lapangan tanpa revisi oleh ahli isi dan ahli media. Dari hasil analisis Uji lapangan diketahui bahwa rerata presentase dari 15 subyek (butir) penilaian yaitu $83,50 \%$ aplikasi pembelajaran masuk dalam kriteria sangat baik.

\section{SIMPULAN}

Kesimpulan yang diperoleh dari hasil dan pembahasan penelitian Aplikasi Augmented Reality Book Sebagai Media Pembelajaran Virus Berbasis Android, antara lain:

Rancangan Augmented Reality Book Media Pembelajaran Virus Berbasis Android menggunakan model ADDIE ADDIE (Analysis-Design-Develop-ImplementEvaluate). Salah satu fungsinya ADDIE yaitu menjadi pedoman dalam membangun perangkat dan infrastruktur program pelatihan yang efektif, dinamis dan mendukung kinerja pelatihan itu sendiri. Model ini menggunakan 5 tahap pengembangan yakni : Analysis (analisa), Design (desain/ perancangan), Development (pengembangan), Implementation (implementasi/eksekusi) dan Evaluation (evaluasi/ umpan balik). Sudah berhasil mengembangkan Aplikasi Augmented Reality Book Virus sesuai dengan alur pengembangan aplikasi yaitu model pengembangnn ADDIE yang dimulai dari tahap analisis pembelajaran/kurikulum dan analisis kebutuhan merupakan kegiatan menentukan pembelajaran yang menjadi objek pengembangan. Berdasarkan proses pengujian aplikasi augmented realily book Virus oleh Ahli Isi dengan rerata 
persentase penilaian sebesar $98,67 \%$, rerata persentase penilaian ahli media sebesar $89,23 \%$, dan rerata presentase respon siswa sebesar 83,50\% maka media aplikasi Augmented Reality Book virus berada dalam kategor sangat baik.

Dalam pegembangan berikutnya agar mempertimbangkan perangkat yang agar mendapatkan hasil yang lebih bagus, detail dari segi objek 3 dimensi dan mempercepat proses dalam mengerjakan objek maupun penggabungan objek 3D dengan marker.

Penggunaan aplikasi dalam kegiatan pembelajaran perlu memperhatikan pendekatan dan teknik yang tepat agar tercipta komumikasi yang baik antara siswa dengan siswa dan siswa dengan guru, sehingga suasana belajar menjadi lebih kondusif dan tujuan dari pembelajaran dapat tercapai.

Aplikasi yang dikembangkan berada dalam lingkup menampilkan animasi objek 3D yang terfokus pada keberhasilan animasi 3D dan menampilkan penjelasan tentang bentuk virus serta jenis-jenis virus beserta reproduksinya, jadi untuk pengembangan selanjutnya diharapkan peningkatan kualitas objek 3 dimensi, animasi dan kelengkapan dari penjelasan virus.

\section{DAFTAR PUSTAKA}

Andriyadi, A. (2011). Augmented Reality With ARToolkit Reality Leaves a lot to imagine. Lampung: Augmented Reality Team

Lisiswanti, (2015). Departemen Patology

Mauludin, R. (2017). Penerapan Augmented Reality Sebagai Media Pembelajaran Sistem Pencernaan pada Manusia dalam Mata Pelajaran Biologi. Jurnal Edukasi dan Penelitian Informatika (JEPIN) Vol. 3, No. 2, p-ISSN : 2460-0741 / e-ISSN : 2548-9364

Nurlifa A, dkk (2016). "Implementasi Augmented Reality untuk Pembelajaran Organ Mata Berbasis Android". Seminar Nasional Ilmu Komputer (SNIK 2016)

Riyana, R. S. (2007). Media Pembelajaran. Bandung: CV. Wacana Prima

Suputra, P. E. (2016). PENGEMBANGAN APLIKASI AUGMENTED REALITY BOOK PENGENALAN GAMELAN TEROMPONG BERUK BERBASIS ANDROID. KARMAPATIi. ISSN 2252-9063.

Suheri. (2006).”Animasi Multimedia Pembelajaran" Jakarta : Elec media Komputindo.

Utami, I, A, A. (2015). "Pengembangan Modul Ajar Interaktif Berbasis Augmented Reality Untuk Mata Pelajaran Jaringan Dasar di SMK NEGERI 3 Singaraja”. Singaraja. 